УДК 535.372:541.49:546.65

\author{
N.N. Semenishyn \\ A. V. Bogatsky Physico-chemical Institute, National Academy of Sciences of Ukraine, \\ Lustdorfskaya doroga 86, 65080, Odessa, Ukraine \\ e-mail:ssmbikola@yahoo.com
}

\title{
LANTHANIDE COMPLEXES WITH REGIOISOMERS OF CHLORO-SUBSTITUTED TETRAPHENYLPORPHYRIN
}

\begin{abstract}
Several isomeric complexes of $\mathrm{Yb}$ (III) and $\mathrm{Lu}(\mathrm{III})$ with $\mathrm{H}_{2}$ tpp and its tetrachloro-substituted derivatives were synthesized. Symmetrical ortho-, meta- and para-positioning of four heavy atoms allows to study their effect on emission features of complexes. Obtained results show the rise of $4 f$-luminescence effectiveness in the row ortho-meta-para isomers.
\end{abstract}

Keywords: lanthanides; porphyrins; isomers; $4 f$-luminescence; sensitization.

Macrocyclic tetrapyrroles were the first among macrocyclic compounds, which reveal $4 f$-luminescence sensitization in the early 1970s [1-2]. Lanthanide complexes with macrocyclic tetrapyrroles are promising as agents for luminescent diagnostics (LD), [3] photodynamic therapy (PDT) [4] and magnetic resonance imaging (MRI) [5] due to their specific luminescent and magnetic properties. Note that $4 f$-luminescence in these complexes is possible in near-infrared (NIR) region only. Lower triplet state $\left(T_{1}\right)$, which is responsible for the sensitization mechanism, can serve as energy donor for lanthanide ions $\mathrm{Yb}^{3+}, \mathrm{Nd}^{3+}$ and $\mathrm{Er}^{3+}$ that have low-lying resonant energy levels. Sensitized $4 f$-luminescence is a quite important phenomenon, which is already used in medicine (drugs, markers, assay) [6], technology (fiber-optics, OLED), etc. NIR4f-luminescence is highly demanded due to several important reasons: light of NIR region can penetrate biological tissues much more effectively in comparison to UV/VIS ranges (UV - ultraviolet, VIS visual) due to very poor overlapping with absorption of bioobjects; NIR light is safe for human in comparison to UV/VIS ranges whose action can generate dangerous radical species; NIR photons undergo much less scattering in comparison to UV/VIS light [7].

Initially, only free bases of porphyrins were used as markers for fluorescence diagnostics and agents for photodynamic therapy [8]. Mainly, these were substances of natural origin, in particular, natural hematoporphyrin. These substances tend to accumulate in tumor tissues and are capable of luminescence [9]. However, the practical use of such markers is associated with two main drawbacks: 1 . The luminescence of porphyrins is observed in the visible range $(600-750 \mathrm{~nm})$ and the luminescent contrast of the image of tumors and other objects obtained with their help is reduced due to the masking effect of the background luminescence of substances, which present in biological tissues. 2 . An inevitable drawback of natural and closely related porphyrins is the phototoxicity of these drugs, which makes it necessary to protect patients from exposure to bright light on the skin for several weeks [10].

So, the present work is devoted to study of emission properties of $\mathrm{Yb}^{3+}$ with ortho-, meta- and para-isomers of tetrachlorosubstituted meso-tetraphenylporphyrin $\left(\mathrm{H}_{2} \mathrm{tpp}\right)$. 


\section{DISCUSSION OF THE RESULTS}

There are three methods for the synthesis of lanthanide porphyrinates (Scheme 1): using 1,4-dichlorobenzene (DCB) [11], 1,2,4-trichlorobenzene (TCB) [3], or imidazole (Im) [12] as a solvent. It should be emphasized that the use of the imidazole method led to a rapid resinification of some porphyrins even in an inert medium in the very first minutes of the synthesis. Thus, the complexes were prepared using TCB and DCB.

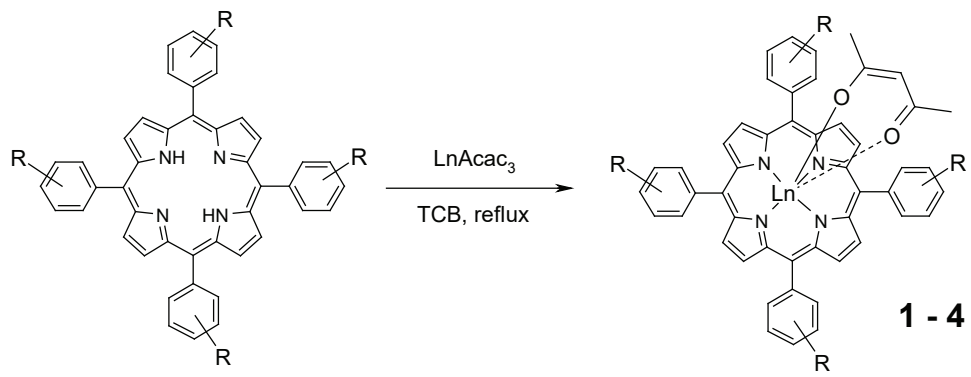

Scheme 1

Synthesis of tetraphenylporphyrinates of lanthanides $(\mathrm{Ln}=\mathrm{Yb}, \mathrm{Lu} ; \mathrm{R}=\mathrm{H}, \mathrm{Cl})$. $1-\mathrm{Ln}=\mathrm{Yb}, \mathrm{R}=\mathrm{H} .2-\mathrm{Ln}=\mathrm{Yb}, \mathrm{R}=o-\mathrm{Cl} .3-\mathrm{Ln}=\mathrm{Yb}, \mathrm{R}=m-\mathrm{Cl} .4-\mathrm{Ln}=\mathrm{Yb}, \mathrm{R}=p-\mathrm{Cl}$.

Acetylacetonate was used as the starting lanthanide compound. This choice is based on the fact that, as was shown earlier, in the case of $\beta$-diketones as extra ligands, the efficiency of $4 f$-luminescence is higher than in the case of halides [3]. In this case, the use of acetylacetonate as an extra ligand in the series of lanthanide porphyrins of the same type with various $\beta$-diketones leads to higher values of the quantum yields of $4 f$ luminescence.

A diagram of the dependence of the yield on the temperature and synthesis time was obtained (Fig. 1). Obtained graph shows that the long synthesis time is accompanied by the pyrolysis of the starting lanthanide acetylacetonates (gray zone: yield $<50 \%$ ); therefore, long-term syntheses are not preferable. It should be noted that although TCB is an optimal synthesis medium, there are nevertheless certain limitations for its use. Firstly, inorganic salts of lanthanides are insoluble in either TCB or DCB; therefore, imidazole is used in this case. Secondly, some porphyrinates cannot be obtained in TCB due to their low thermal stability, such as modified porphyrins. An attempt to use DMF as a synthesis medium did not lead to satisfactory results, since during 48 hours of synthesis, no complex appeared in the system, and after this time, it was not possible to detect the starting acetylacetonate, which completely underwent pyrolysis.

Thus, we used the procedure for preparing complexes in TCB, since the yield in this case is highest. The synthesis was carried out using lanthanide acetylacetonate as salt according to the scheme (Scheme 1) with the formation of complexes with the ratio lanthanide: porphyrin: extra-ligand $=1: 1: 1$. In the FAB mass spectra of all complexes, the molecular ion peak is absent. The most intense peak belongs to the fragment Ln-Porph ${ }^{+}$. NMR spectra recorded for Lu-complexes only (other lanthanide ions act as strong shift 


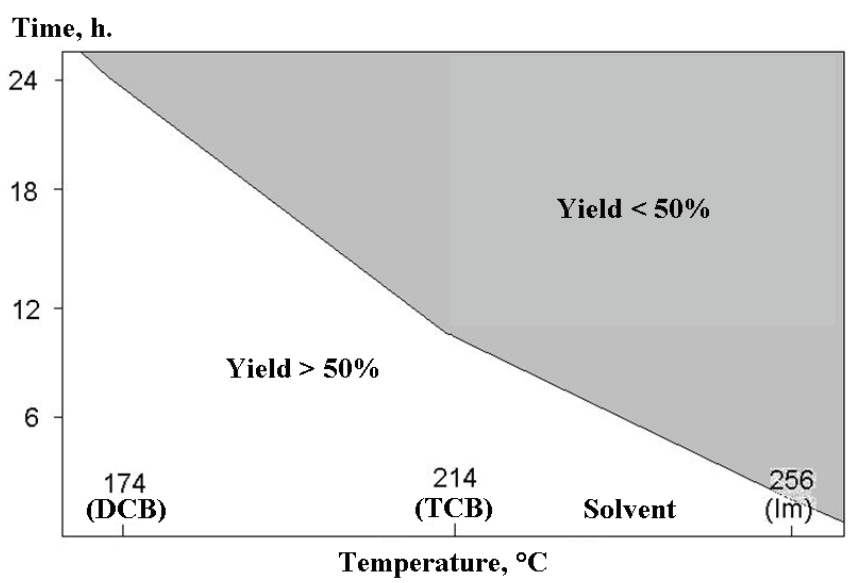

Fig. 1. Diagram: yield of the complexes - temperature - synthesis time

agents and NMR spectra became quite hard for the interpretation). Phosphorescence spectra of Lu-complexes were recorded to determine the $\mathrm{T}_{1}$ (lower triplet) levels.

meso-Tetraarylporphyrins are characterized by the etio-type of the absorption spectrum - the increase in the intensities of the $Q$-bands occurs in the following order: I $<$ II $<$ III $<$ IV. Data on the absorption spectra of the studied ligands and their complexes are presented in Table 1. The introduction of phenyl substituents (1) leads to a bathochromic shift of all four $Q$-bands, as well as the Soret band, in comparison with porphine (Por). The electron-withdrawing substituent -Cl in para-position (compound 4) has practically no effect on the position of the bands in the absorption spectra of ligands in comparison with $\mathrm{H}_{2}$ tpp.

The study of regioisomers $\mathbf{2}, \mathbf{3}$ and $\mathbf{4}$ with different spatial arrangements of substituents in the structure of porphyrins and their complexes allows finding dependence of both absorption spectra and luminescence properties on its location in the structure.

The introduction of the $\mathrm{Cl}$-substituent into the phenyl rings changes the absorption spectra of the ligands: the greatest changes are observed for ortho-derivatives - the bathochromic shift of the first band is $38 \mathrm{~nm}$ compared to porphine and $5 \mathrm{~nm}$ compared to $\mathrm{H}_{2}$ tpp. The substituents in the meta- and para-positions change the absorption spectra lesser.

The results confirmed that ortho-substitution has the most significant effect on the absorption spectra due to a change in the conformation of the $\mathrm{C}-\mathrm{C}$ bond of the mesocarbon atom and the carbon atom in the first position of the phenyl group. In this case, the phenyl rings are almost at a right interplanar angle to the macroring.

Molecular fluorescence of tetraarylporphyrins is realized due to the radiative transition $\mathrm{S}_{1} \rightarrow \mathrm{S}_{0}$. The luminescence parameters of all $\mathrm{H}_{2}$ tpp derivatives have comparable values (Table 1). Substitution in the para-position of phenyl has practically no effect on the quantum yield and the luminescence lifetime of the porphyrins. A decrease in these values for halogen derivatives is associated with the internal effect of a heavy atom, which leads to an increase in the probability of intramolecular intercombination transi- 


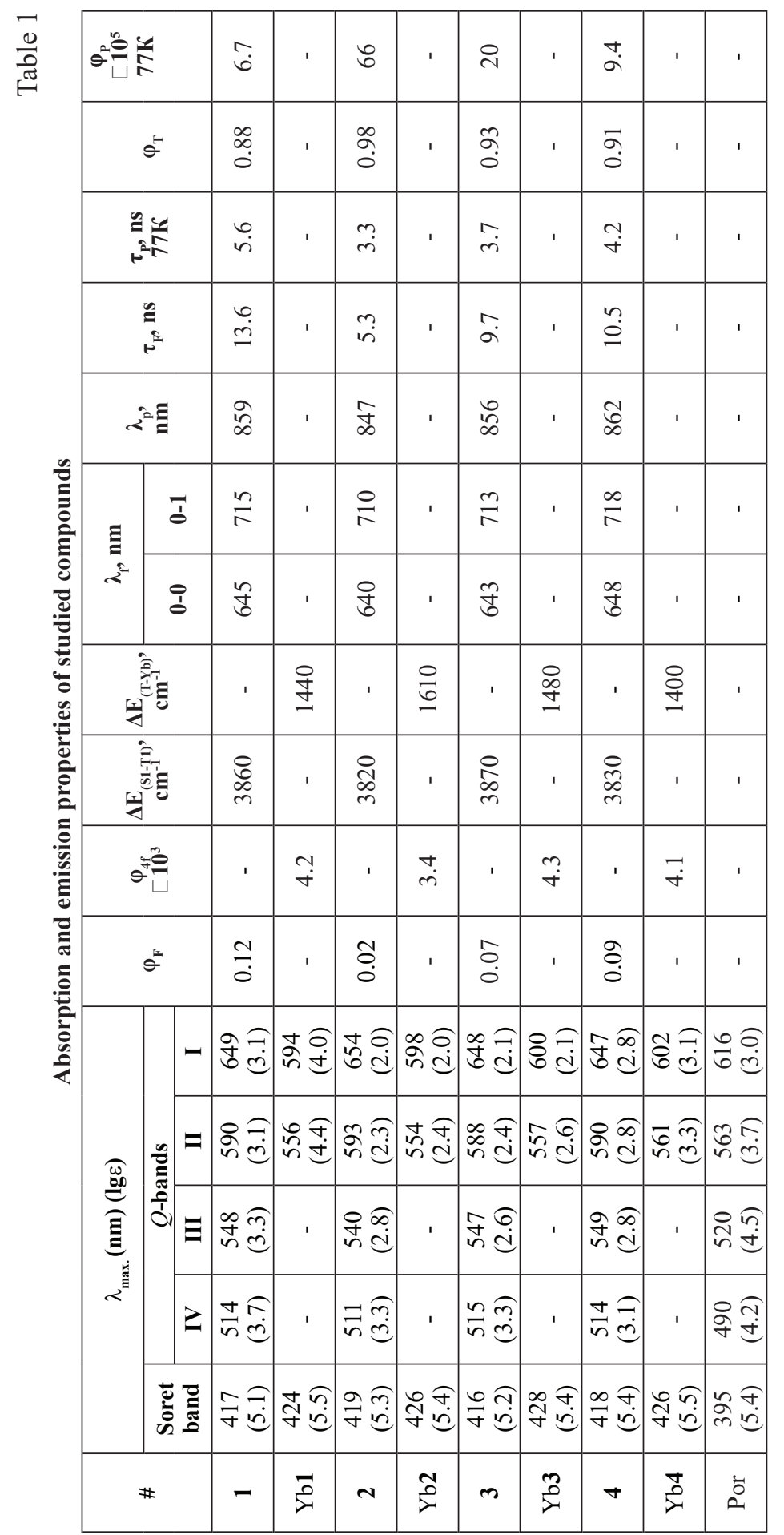


tions (IIT). This results in quenching of fluorescence and a reduction in the lifetime of the $T_{1}$-state. Despite the fact that, due to the non-coplanarity of phenyl rings with porphyrin, chlorine atoms are largely isolated from the conjugated chromophore system, in the studied systems the phosphorescence quantum yield $\left(\varphi_{\mathrm{p}}\right)$ sharply increases as the halogen atom moves from para- to ortho-position from $9.4 \cdot 10^{-5}$ to $6.6 \cdot 10^{-4}$. This means that the singlet states are mixed with the $\mathrm{T}_{1}$ state under the influence of heavy atoms. Thus, a decrease in the fluorescence quantum yield $\left(\varphi_{\mathrm{F}}\right)$ and an increase in the quantum yield of intercombination conversion $\left(\varphi_{\mathrm{T}}\right)$ are in good agreement with an increase in the phosphorescence efficiency ( $\varphi_{\mathrm{p}}$-phosphorescence quantum yield) in the series of para-, meta-, and ortho-chloro-substituted $\mathrm{H}_{2}$ tpp derivatives.

The lifetime of molecular fluorescence $\left(\tau_{\mathrm{F}}\right)$ decreases like the quantum yield in the series of para-, meta-, and ortho-chloro-substituted $\mathrm{H}_{2}$ tpp derivatives and does not change in the series of various substituted para $-\mathrm{H}_{2}$ tpp derivatives (Table 1).

The shift of the phosphorescence band maximum is observed in the case of a change in the position (Table 1). Thus, upon going from the para- to meta-position, the hypsochromic shift is $6 \mathrm{~nm}$, and from the meta- to ortho-position, $9 \mathrm{~nm}$. This is a consequence of the close location of the chlorine substituent to the porphyrin chromophore, which causes a redistribution of the electron density and consequently affects the position of the triplet emitting level.

Luminescence of $\mathrm{Yb}^{3+}$ ions is observed in all studied complexes (Fig.2) in the region of $980 \mathrm{~nm}$ upon excitation in a wide spectral range $(300-600 \mathrm{~nm})$; however, it is most efficiently realized upon excitation at the maximum of the Soret band. The almost complete similarity of the $4 f$-luminescence excitation spectra of $\mathrm{Yb}^{3+}$ in porphyrinates with their absorption spectra indicates that $\mathrm{Yb}^{3+}$ ions serve as acceptors of the excitation energy from the organic part of the complex.

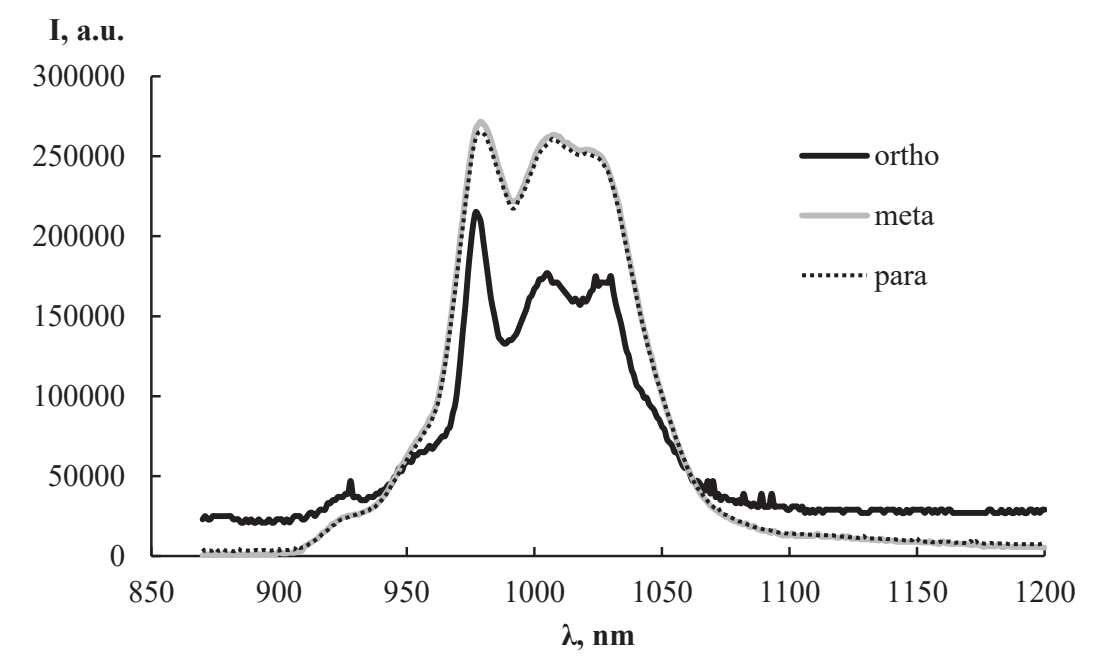

Fig. 2. Non-smoothed (original) $4 f$-luminescence spectra of $Y b$-complexes 2, 3 and 4 (ortho-, meta- and para-isomers of tetrachloro-substituted $\mathrm{Yb}$-tpp) 
Difference between the values of the triplet and singlet levels of the complex, as well as the triplet and resonance levels of the ytterbium ion ${ }^{2} \mathrm{~F}_{5 / 2}$, does not undergo significant changes in the series of complexes with para-substituted $\mathrm{H}_{2}$ tpp derivatives. For complexes with meta- and para-isomers of meso-tetrachlorophenylporophyrin, the values of $4 f$-luminescence quantum yields also hardly differ, in contrast to the complex with the ortho-isomer ( $\varphi_{4 \mathrm{f}}=3.4$ is the minimum value in the presented series). It is obvious that the effect of the heavy atom is most pronounced in this isomer, since the distance from the chlorine atom to the emitting ion in this case is minimal. Recently, it was shown that such ortho-positioning of substituent in macrocyclic tetrapyrroles even can lead to formation of prototropic isomers due to electronic redistribution [13]. It should also be noted that the difference between the lower triplet state of the complex and the resonance level ${ }^{2} \mathrm{~F}_{5 / 2}$ in this case is maximum, which suggests the presence of additional ways of deactivation of the excitation energy.

It should be emphasized that the values of the quantum yield for all the studied Ybtetraarylporphyrinates are significantly higher than for all Yb-tetraalkylporphyrinates, which were studied earlier [14]. This effect is associated with the presence of partial conjugation of the phenyl rings at the meso-positions, and, as a consequence, a higher population of all energy levels, including the $T_{1}$ level, from which the energy is transferred to the resonance level of the $\mathrm{Yb}^{3+}$ ion. Another possible explanation is that the first carbon atom of the meso-substituent does not contain $\mathrm{C}-\mathrm{H}$ bonds, the vibrational absorption bands of which are close to the value of the $\mathrm{T}_{1} \rightarrow{ }^{2} \mathrm{~F}_{7 / 2}$ transition. In meso-tetraalkylporphyrins, on the contrary, the first carbon atom contains two such bonds, which, apparently, is reflected in a sharp decrease in the $4 f$-luminescence intensity.

To conclude, we synthesized several regioisomeric complexes of $\mathrm{Yb}$ (III) and $\mathrm{Lu}(\mathrm{III})$ on the base of chloro-substituted $\mathrm{H}_{2}$ tpp. It was found out, that values of the quantum yield of arylporphyrinates of ytterbium are significantly higher than for alkylporphyrinates. Position of the heavy atoms in four phenyl rings of Yb-tpp affects its photophysical features drastically, thus in the row ortho-meta-para isomers IIT slows down, which leads to increase of $\varphi_{\mathrm{F}}, \varphi_{4 \mathrm{f}}, \tau_{\mathrm{F}}$, and, on the other hand to decrease of $\varphi_{\mathrm{T}}$ and $\varphi_{\mathrm{P}}$.

\section{EXPERIMENTAL PART}

Spectra of molecular fluorescence, $4 f$-luminescence and excitation spectra were recorded on a spectrofluorimeter "Fluorolog FL 3-22" ("Horiba Jobin Yvon") using 450 W Xe-lamp. Spectra of molecular fluorescence of porphyrins, corroles and phthalocyanines were registered at $550-800 \mathrm{~nm}\left(\mathrm{~S}_{1}-\mathrm{S}_{0}\right.$ transitions). Integral intensity of luminescence was measured using software of the device. The relative quantum yield of molecular fluorescence $\left(\varphi_{\mathrm{F}}\right)$ was determined using solution of $\mathrm{Zn}$-tpp in ethanol as a primary standard (0.022). Determination of the $\varphi_{\mathrm{F}}$ (accuracy is $\pm 10 \%$ ) was made using formula:

$$
\varphi_{\mathrm{F}}=\varphi_{0} \mathrm{I}_{\mathrm{x}} \mathrm{A}_{0} \mathrm{n}_{\mathrm{x}}{ }^{2} /\left(\mathrm{I}_{0} \mathrm{~A}_{\mathrm{x}} \mathrm{n}_{0}{ }^{2}\right),
$$

where $\varphi_{0}$ and $\varphi_{\mathrm{x}}$ - luminescence quantum yield of the standard and of the sample respectively,

$A_{0}$ and $A_{x}$ - absorption at the wavelength of Soret band of the standard and of the sample respectively, 
$\mathrm{I}_{\mathrm{x}}$ and $\mathrm{I}_{0}$ - integral luminescence intensity of the standard and of the sample respectively,

$\mathrm{n}_{0}$ and $\mathrm{n}_{\mathrm{x}}-$ refractive index of the standard solvent and of the sample solvent respectively.

Fluorescence lifetime $(\tau)$ was measured under excitation at the Soret band.

Purity of the obtained compounds was checked by TLC Sorbfil plates (grain 5-17 $\mu \mathrm{m}$, UV-254, thickness $0.1 \mathrm{~mm}$ ) by Imid Ltd. ${ }^{1} \mathrm{H}$ NMR-spectra were recorded using Bruker Avance 600 or $400 \mathrm{MHz}$ in $\mathrm{CD}_{3} \mathrm{OD}$. Mass spectra FAB were recorded on a Varian MAT $\mathrm{CH}-112$ spectrometer (Varian BV, Middelburg) using m-nitrobenzylalcohol as the matrix. Elemental analysis was performed on CHNS analyzer Flash 2000 Thermo Scientific.

Synthesis of starting porphyrins and complexes was performed accordingly to known procedures for these compounds [15-18].

\section{REFERENCES}

1. Kachura T. F., Sevchenko A.N., Solov'ev K. N., Tsvirko M.P. Intramolecular transfer of electron excitation energy in porphyrin complexes of ytterbium // Dokl. Phys. Chem.- 1974.- Vol. 217, N5.- P. 1121-1124. (in Russian)

2. Gouterman M., Schumaker C.D., Srivastava T.S., Yonetani T. Absorption and luminescence of yttrium and lanthanide octaethylporphin complexes // Chem. Phys. Lett.- 1976.- Vol. 40, N3.- P. 456-461. http://dx.doi.or g/10.1016/0009-2614(76)85118-4

3. Tsvirko M., Korovin Yu., Rusakova N. Ytterbium-porphyrins as a new class of the luminescent labels // J. Physics: Conference Series.- 2007.- Vol. 79.- P. 012025. http://dx.doi.org/10.1088/1742-6596/79/1/012025

4. Zang L., Zhao H., Hua J., Qin F., Zheng Y., Zhang Z., Cao W. Water-soluble gadolinium porphyrin as a multifunctional theranostic agent: Phosphorescence-based oxygen sensing and photosensitivity // Dyes Pigments.-2017.- Vol. 142.- P. 465-471. https://doi.org/10.1016/j.dyepig.2017.03.056

5. Tsolekile N., Nelana S., Oluwafemi O. S. Porphyrin as Diagnostic and Therapeutic Agent // Molecules.-2019.Vol. 24, N14.- P. 2669. https://doi.org/10.3390/molecules24142669

6. Kaczmarek $M$. Lanthanide-sensitized luminescence and chemiluminescence in the systems containing most often used medicines; a review // J. Luminescence.- 2020.- Vol. 222.- P. 117174. https://doi.org/10.1016/j. jlumin.2020.117174

7. Martinić I., Eliseeva S. V., Petoud S. Near-infrared emitting probes for biological imaging: Organic fluorophores, quantum dots, fluorescent proteins, lanthanide(III) complexes and nanomaterials // J. Luminescence.- 2017.Vol. 189.- P. 19-43. https://doi.org/10.1016/j.jlumin.2016.09.058

8. Doiron D.R., Keller Y.S. Porphyrin photodynamic therapy: principles and clinical applications. Karger, Basel.1986.- Vol 15.- P. 85-93. https://doi.org/10.1159/000412094

9. Kamalov V.F., Stepanova N. V., Cherniaeva E. B., Chikishev A. Yu. Selective effects of laser radiation on cancer cells and laser spectroscopy of cells // Quantum Electron.- 1985.- Vol. 12, N10.- P. 1997-2023.

10. Gaiduk M.I., Grigoryants V.V., Mironov A.F., Roytman L.D., Chissov V.I., Rumyantseva V.D., Sukhin G.M. Luminescence diagnostics of neoplasms in the IR-range using metal-complexes of porphyrins // Dokl. AN SSSR.-1989.- Vol. 309, N4.- P. 980-983. (in Russian)

11. Semenishyn N. N., Rusakova N. V., Mazepa A. V., Korovin Yu. V. Synthesis of Ditopic Porphyrins and Lanthanide Complexes on their Basis: Luminescent Features // Macroheterocycles.- 2009.- Vol. 2, N1.- P. 57-59. https://doi.org/10.6060/mhc2009.1.57

12. Le Roy J.J., Cremers J., Thomlinson I.A., Slota M., Myers W.K., Horton P.H., Coles S.J., Anderson H.L., Bogani L. Tailored homo- and hetero- lanthanide porphyrin dimers: a synthetic strategy for integrating multiple spintronic functionalities into a single molecule // Chem. Sci.-2018.- Vol. 9, N45.- P. 8474-8481. https://doi. org/10.1039/c8sc03762k

13. Semenishyn N.N., Ognichenko L.N., Smola S. S., Rusakova N. V. Regioisomers of Mononitro- and MonoaminoA2B-Corroles: Synthesis and Unusual Luminescence Behavior// ChemistrySelect.-2019.-Vol.4, N35.P. 10340-10345. https://doi.org/10.1002/slct.201902777

14. Rusakova N.V., Semenishyn N.N., Zhilina Z.I., Vodzinskii S.V., Korovin Yu.V.. Synthesis and luminescent properties meso-tetra-(n-alkyl)-porphyrinates of ytterbium // Ukr. Chem. J.- 2008.- Vol. 72, N7.- P. 3-7. (in Russian) 
15. Yanheng Y., Wenyun $W$. Preparation and UV-VIS spectra of rare earth complexes of tetrakis(o-chlorophenyl) porphine // Chengdu Keji Daxue Xuebao.-1986.-Vol.2, P. 35-40. (in Chines)

16. Guofa L., Yuanfu Z. Preparation and properties of acetyl acetonate-5,10,15,20-tetra(o-chlorophenyl) and tetra(m-chlorophenyl)porphyrin rare earth complexes // Huaxue Xuebao.- 1985.- Vol. 43, N11.- P. 1104-1106. (in Chines)

17. Shen H.M., Wang X., Guo A. B., Zhang L., She Y. B. Catalytic oxidation of cycloalkanes by porphyrin cobalt(II) through efficient utilization of oxidation intermediates // J. Porphyrins Phthalocyanines. - 2020.- Vol. 24, N10.P. 1166-1173. https://doi.org/10.1142/s1088424620500303

18. Shen H.-M., Wang X., Ning L., Guo A.B., Deng J.-H., She Y.-B. Efficient oxidation of cycloalkanes with simultaneously increased conversion and selectivity using $\mathrm{O}_{2}$ catalyzed by metalloporphyrins and boosted by $\mathrm{Zn}(\mathrm{AcO})_{2}$ : A practical strategy to inhibit the formation of aliphatic diacids // Appl. Catalysis A: General.2021.- Vol. 609.- P. 117904. https://doi.org/10.1016/j.apcata.2020.117904

Стаття надійшла до редакції 14.07.2021

\section{М. М. Семенішин}

Фізико-хімічний інститут ім. О.В. Богатського НАН України, вул. Люстдорфська дорога, 86, Одеса 65080, Україна;

e-mail: ssmbikola@yahoo.com

\section{КОМПЛЕКСИ ЛАНТАНІДІВ 3 РЕГІОІЗОМЕРАМИ ХЛОРОЗАМНЩЕНОГО ТЕТРАФЕНІЛПОРФІРІНУ}

В роботі було синтезовано декілька регіоізомерних комплексів ітербію (III) та лютецію (III) 3 мезо-тетрафенілпорфірином та його тетрахлор-заміщеними похідними. Вивчено особливості протікання синтезу комплексів лантанідів 3 похідними мезотетрафенілпорфірину. Показано, що серед існуючих одностадійних процесів синтезу 1,4-дихлобензол та 1,2,4-трихлорбензол є оптимальними середовищами для проведення синтезу. Головним чином це пов’язано $з$ деструкцією/піролізом як деяких вихідних порфіринів, так і багатьох вихідних сполук лантанідів у разі використання імідазолу в якості середовища. Власна флуоресценція хлорпохідних порфіринів спостерігається в звичайному діапазоні 600-750 нм, але їі ефективність помітно знижується у ряду парамета-орто-ізомерів. На відміну від комплексів ітербію з мезо-тетраалкілпорфіринами, всі представлені комплекси на основі похідних мезо-тетрафенілпорфірину мають доволі високу ефективність $4 f$-люмінесценції іону ітербію. Симетричне орто-, мета- та пара-позиціонування чотирьох «важких» атомів хлору дозволяє вивчити їх вплив на емісійні особливості комплексів в залежності від відстані до хромофору порфірину та іону-випромінювачу. Основний фактор, який чинить «важкий» атом емісійній системі комплексу це прискорення внутрішньомолекулярної інтеркомбінаційної конверсії. Про це, зокрема, свідчить підвищення квантового виходу інтеркомбінаційної конверсії з 0.88 до 0.98 яка, внаслідок дії «важких» атомів може краще конкурувати з іншими фотофізичними процесами у молекулі. 3 іншого боку наслідком такого явища $\epsilon$ підвищення квантового виходу фосфоресценції порфірину на порядок (з $6.7 \cdot 10^{-5}$ до $\left.6.6 \cdot 10^{-4}\right)$. Отримані результати демонструють зростання ефективності $4 f$-люмінесценції іону ітербію при переході 3 орто- до мета- та пара-ізомерів комплексів $33.4 \cdot 10^{-3}$ до $4.3 \cdot 10^{-3}$

Ключові слова: лантаніди; порфірини; ізомери; $4 f$-люмінесценція; сенсибілізація. 


\section{Н.Н. Семенишин}

Физико-химический институт им. А. В. Богатского НАН Украины, ул. Люстдорфская дорога, 86, Одесса, 65080, Украина; e-mail:ssmbikola@yahoo.com

\section{КОМПЛЕКСЫ ЛАНТАНИДОВ С РЕГИОИЗОМЕ РАМИ ХЛОРОЗАМЕЩЕННОГО ТЕТРАФЕНИЛПОРФИРИНА}

В работе были синтезированы несколько региоизомерних комплексов иттербия (III) и лютеция (III) с мезо-тетрафенилпорфирином и его тетрахлоро-замещенными производными. Изучены особенности протекания синтеза комплексов лантанидов с производными мезо-тетрафенилпорфирина. Показано, что среди существующих одностадийных процессов синтеза, 1,4-дихлобензол и 1,2,4-трихлорбензол являются оптимальными средами для проведения синтеза. Главным образом это связано с деструкцией/пиролизом как некоторых исходных порфиринов, так и многих исходных соединений лантанидов при использовании имидазола в качестве среды. Собственная флуоресценция хлорпроизводных порфиринов наблюдается в обычном диапазоне 600-750 нм, но её эффективность заметно снижается в ряду пара-мета-орто-изомеров. В отличие от комплексов иттербия с мезо-тетраалкилпорфиринами, все представленные комплексы на основе производных мезо-тетрафенилпорфирину имеют достаточно высокую эффективность $4 f$-люминесценции иона иттербия. Симметричное орто-, метаи пара-позиционирование четырех «тяжёлых» атомов хлора позволяет изучить их влияние на эмиссионные особенности комплексов в зависимости от расстояния до хромофора порфирина и иона-излучателя. Основной фактор, который оказывает «тяжёлый» атом эмиссионной системе комплекса, это ускорение внутримолекулярной интеркомбинационной конверсии. Об этом, в частности, свидетельствует повышение квантового выхода интеркомбинационной конверсии с 0.88 до 0.98 , которая, вследствие действия «тяжелых» атомов, может лучше конкурировать с другими фотофизическими процессами в молекуле. С другой стороны, как следствие этого явления, наблюдается повышение квантового выхода фосфоресценции порфирина на порядок (с $6.7 \cdot 10^{-5}$ до $\left.6.6 \cdot 10^{-4}\right)$. Полученные результаты демонстрируют рост эффективности $4 f$-люминесценции иона иттербия при переходе с орто- к мета- и пара-изомерам комплексов с $3.4 \cdot 10^{-3}$ до $4.3 \cdot 10^{-3}$.

Ключевые слова: лантаниды; порфирины; изомеры; $4 f$-люминесценция; сенсибилизация.

\section{REFERENCES}

1. Kachura T. F., Sevchenko A.N., Solov'ev K. N., Tsvirko M.P. Intramolecular transfer of electron excitation energy in porphyrin complexes of ytterbium. Dokl. Phys. Chem., 1974, vol. 217, no 5, pp. 1121-1124. (in Russian)

2. Gouterman M., Schumaker C.D., Srivastava T.S., Yonetani T. Absorption and luminescence of yttrium and lanthanide octaethylporphin complexes. Chem. Phys. Lett.,1976, vol.40, no 3, pp. 456-461. http://dx.doi.org/1 0.1016/0009-2614(76)85118-4

3. Tsvirko M., Korovin Yu., Rusakova N. Ytterbium-porphyrins as a new class of the luminescent labels. J. Physics: Conference Series, 2007, vol. 79, pp. 012025. http://dx.doi.org/10.1088/1742-6596/79/1/012025

4. Zang L., Zhao H., Hua J., Qin F., Zheng Y., Zhang Z., Cao W. Water-soluble gadolinium porphyrin as a multifunctional theranostic agent: Phosphorescence-based oxygen sensing and photosensitivity. Dyes Pigments., 2017, vol. 142, pp. 465-471. https://doi.org/10.1016/j.dyepig.2017.03.056

5. Tsolekile N., Nelana S., Oluwafemi O. S. Porphyrin as Diagnostic and Therapeutic Agent. Molecules., 2019, vol.24, no 14, pp. 2669. https://doi.org/10.3390/molecules24142669

6. Kaczmarek M. Lanthanide-sensitized luminescence and chemiluminescence in the systems containing most often used medicines; a review. J. Luminescence, 2020, vol. 222, pp. 117174. https://doi.org/10.1016/j. jlumin.2020.117174 
7. Martinić I., Eliseeva S. V., Petoud S. Near-infrared emitting probes for biological imaging: Organic fluorophores, quantum dots, fluorescent proteins, lanthanide(III) complexes and nanomaterials. J. Luminescence, 2017, vol. 189, pp. 19-43. https://doi.org/10.1016/j.jlumin.2016.09.058

8. Doiron D.R., Keller Y.S. Porphyrin photodynamic therapy: principles and clinical applications. Karger, Basel, 1986, vol 15, pp. 85-93. https://doi.org/10.1159/000412094

9. Kamalov V.F., Stepanova N. V., Cherniaeva E. B., Chikishev A. Yu. Selective effects of laser radiation on cancer cells and laser spectroscopy of cells. Quantum Electron, 1985, vol.12, no 10, pp. 1997-2023.

10. Gaiduk M.I., Grigoryants V.V., Mironov A.F., Roytman L.D., Chissov V.I., Rumyantseva V.D., Sukhin G.M. Luminescence diagnostics of neoplasms in the IR-range using metal-complexes of porphyrins. Dokl. AN SSSR, 1989, vol. 309, no 4, pp. 980-983. (in Russian)

11. Semenishyn N. N., Rusakova N.V., Mazepa A.V., Korovin Yu. V. Synthesis of Ditopic Porphyrins and Lanthanide Complexes on their Basis: Luminescent Features. Macroheterocycles, 2009, vol. 2, no 1, pp. 57-59. https://doi.org/10.6060/mhc2009.1.57

12. Le Roy J.J., Cremers J., Thomlinson I.A., Slota M., Myers W.K., Horton P.H., Coles S. J., Anderson H.L., Bogani L. Tailored homo- and hetero- lanthanide porphyrin dimers: a synthetic strategy for integrating multiple spintronic functionalities into a single molecule. Chem. Sci., 2018, vol. 9, no 45, pp. 8474-8481. https://doi. org $/ 10.1039 / \mathrm{c} 8 \mathrm{sc} 03762 \mathrm{k}$

13. Semenishyn N.N., Ognichenko L.N., Smola S.S., Rusakova N.V. Regioisomers of Mononitro- and Monoamino-A2B-Corroles: Synthesis and Unusual Luminescence Behavior. Chem. Select, 2019, vol. 4, no 35 , no. 10340-10345. https://doi.org/10.1002/slct.201902777

14. Rusakova N.V., Semenishyn N.N., Zhilina Z.I., Vodzinskii S. V., Korovin Yu.V.. Synthesis and luminescent properties meso-tetra-(n-alkyl)-porphyrinates of ytterbium. Ukr. Chem. J., 2008, vol. 72, no 7, pp. 3-7. (in Russian)

15. Yanheng Y., Wenyun W. Preparation and UV-VIS spectra of rare earth complexes of tetrakis(o-chlorophenyl) porphine. Chengdu Keji Daxue Xuebao, 1986, vol. 2, pp. 35-40. (in Chines)

16. Guofa L., Yuanfu Z. Preparation and properties of acetyl acetonate-5,10,15,20-tetra(o-chlorophenyl) and tetra(m-chlorophenyl)porphyrin rare earth complexes// Huaxue Xuebao, 1985, vol. 43, no 11, pp. 1104-1106. (in Chines)

17. Shen H.M., Wang X., Guo A. B., Zhang L., She Y. B. Catalytic oxidation of cycloalkanes by porphyrin cobalt(II) through efficient utilization of oxidation intermediates. J. Porphyrins Phthalocyanines, 2020, vol. 24, no 10, pp. 1166-1173. https://doi.org/10.1142/s1088424620500303

18. Shen H.-M., Wang X., Ning L., Guo A.B., Deng J.-H., She Y.-B. Efficient oxidation of cycloalkanes with simultaneously increased conversion and selectivity using $\mathrm{O}_{2}$ catalyzed by metalloporphyrins and boosted by $\mathrm{Zn}(\mathrm{AcO})_{2}:$ A practical strategy to inhibit the formation of aliphatic diacids. Appl. Catalysis A: General., 2021, vol. 609, pp.117904. https://doi.org/10.1016/j.apcata.2020.117904 